\title{
Staphylococcal infection in subdivided general surgical wards
}

\author{
By P. N. EDMUNDS \\ Fife District Laboratory, Kirkcaldy, Fife
}

(Received 18 May 1970)

\section{SUMMARY}

The spread of Staphylococcus aureus was studied in three general surgical wards of identical design which consisted of a number of separate rooms, and the results were compared with those in the same unit previously studied, in subdivided wards elsewhere and in large open wards.

The nasal carrier rate of Staph. aureus by patients rose during their stay in the ward, but its peak rate was comparable with minimum rates reported in other subdivided wards and was lower than in open wards.

Staphylococcal sepsis rates were lower than in most open wards and were also much lower than those found previously in the same unit when overcrowding was common and each sex had its own ward.

\section{INTRODUCTION}

One of the features of recent hospital designs has been the adoption of separate rooms within each ward, mostly containing four patients or less. One reason for this is to reduce the level of cross-infection. This paper investigates the extent to which this has been successful in three general surgical wards in a recently built District General Hospital in Fife.

\section{Architecture and ventilation}

All three wards have the lay-out shown in Fig. 1. Wards A and B are on the first and second floors of the south wing and ward $\mathrm{C}$ on the second floor of the east wing of the building, which has three floors and a basement. There are one 8-bed, four 4-bed and four 1-bed rooms in each ward. The 8-bed rooms measure $45 \mathrm{ft}$. by $20 \mathrm{ft}$., the 4 -bed $20 \mathrm{ft}$. square, and 1-bed $20 \mathrm{ft}$ by $10 \mathrm{ft}$. Ceiling height is $10 \mathrm{ft}$. Each room has a door, which is usually left open. Ventilation is natural. Ward doors leading to the central staircase are normally shut, but those leading to the peripheral staircase are usually left open. Also included in the block are a paediatric ward on the ground floor, south wing, the pharmacy on ground floor, east wing and a urology ward and dermatology out-patient unit on the first floor of the east wing.

The west wing, not shown in Fig. 1, comprises the X-Ray department and offices on the ground floor, residency on the first floor and a suite of one small and two main operating theatres on the second floor, which serves the whole block. The theatres are ventilated by positive pressure at between 15 and 20 air changes per hour. 
Floors were cleaned daily with a vacuum cleaner, and by mopping and polishing. Bed curtains were hot-laundered about once every 5 weeks and the cotton blankets after discharge of each patient. Otherwise, no special measures against cross-infection were in operation and the hospital did not have an active Control of Infection Committee during the investigation. There was no Control of Infection Officer or Sister.

Air movements were not studied in detail, but the presence of open doorways leading to the peripheral staircase must have led to a considerable exchange of air

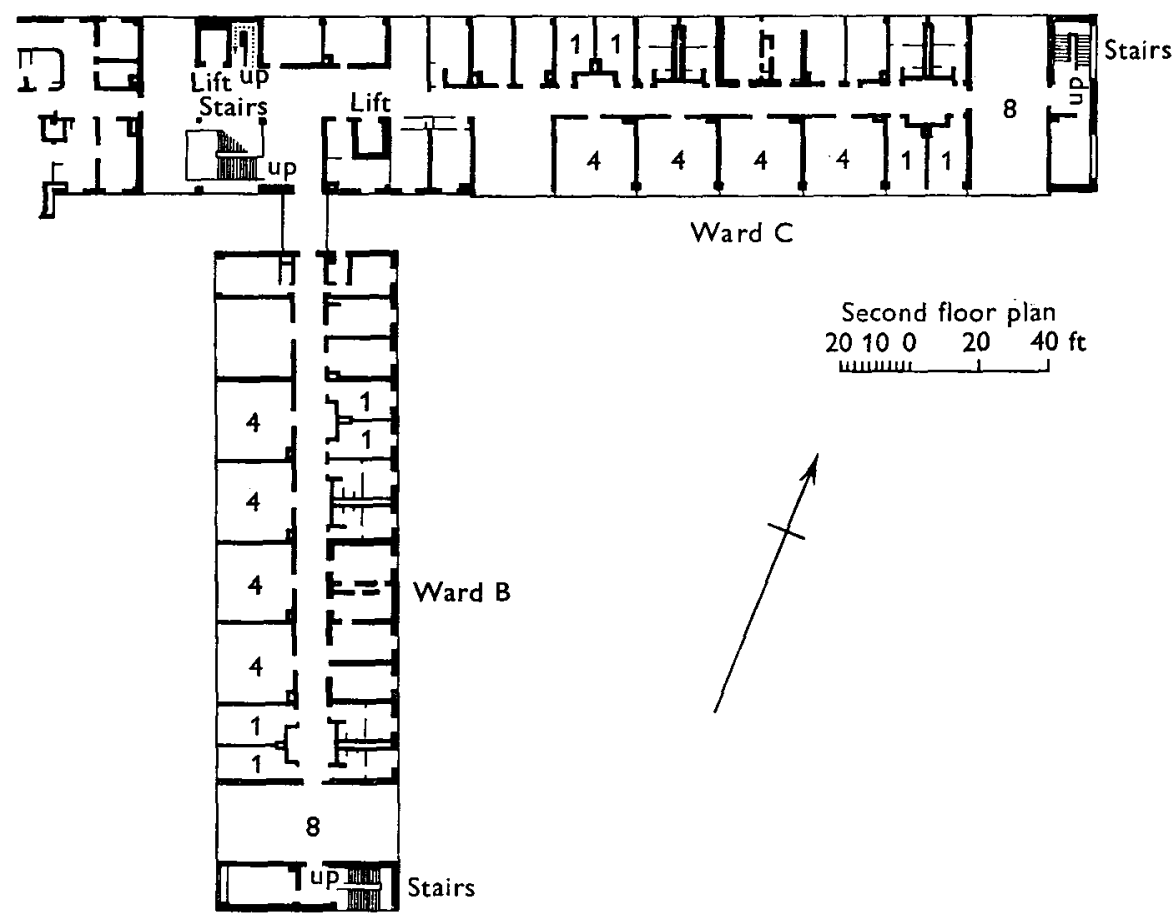

Fig. 1. Plan of wards B and C. Bed-rooms and their bed complements are indicated by the numerals 1,4 or 8 .

between wards $\mathrm{A}$ and $\mathrm{B}$. The doors between the paediatric ward and the south and central stair wells were normally kept shut so that air from this ward was unlikely to move in large amounts to wards A and B above it. At the distal end of ward $C$ the staircase led down to an outside door in frequent use by out-patients, so that considerable ventilation by fresh outside air must have occurred through the open doors at this end of the ward.

\section{METHODS \\ Patients}

In all three wards both 1-bed and 4-bed rooms were used for either males or females, but females always occupied the 8-bed rooms. In ward $\mathrm{C}$ female patients were sometimes admitted to the 8 -bed room prior to undergoing an operation, 
followed by transfer to one of the other rooms. In wards A and B most patients admitted to 8-bed rooms remained there throughout their stay. In all three wards there was little movement of patients from 1-bed or 4-bed rooms to other room types.

\section{Wound dressings}

In ward A, clean wounds were sprayed with Nobecutane but otherwise left uncovered. In the other two wards dressings were used, which were removed on the 2nd or 3rd day after operation. Stitches were removed on the 8th and 9th days.

Wounds were considered to be septic only when visible pus was present and this was recorded only in major clean or potentially infected operation wounds, e.g. hernia (clean) or uncomplicated appendicectomy (potentially infected). Wounds where gross fouling occurred from a contaminated viscus (e.g. ruptured appendix) or where pus was already present at operation, were excluded from the investigation. 'Staphylococcal other sepsis' was recorded in any clinical infection arising in hospital, other than wound sepsis as defined above, from which Staph. aureus was isolated in significant numbers. It thus included respiratory, urinary or cutaneous infections and infections of minor surgical wounds such as drip incisions. It did not include infections already present on admission. Ascertainment of sepsis was made by following up routine bacteriology specimens sent to the laboratory.

\section{Antibiotic treatment}

Patients in ward C having operations usually had penicillin and streptomycin both as a local wound application and intramuscularly for several days after operation. There was no routine prophylactic administration of antibiotics in the other two wards. The percentages of patients receiving antibiotics in wards $\mathrm{A}, \mathrm{B}$ and $\mathrm{C}$ were $39 \cdot 7,23 \cdot 2$ and $34 \cdot 1$ respectively; and in all wards, $31 \cdot 7$.

\section{Staff}

Each ward had one consultant surgeon. In addition, there were 6 beds in ward A looked after by a consultant urologist. The medical staff included one registrar and one house officer in each ward and an additional senior house officer in ward A. There were a sister, two staff nurses, two state-enrolled nurses and eight nursing trainees and auxiliaries in each ward during the day, with two to three nurses at night. Other professional staff included three anaesthetists and one physiotherapist shared between the three wards. There were three domestic staff in each ward.

\section{Bacteriological examinations}

Nasal swabs were taken from patients on admission and thereafter weekly on a fixed day, and weekly from surgical, nursing and other staff of the ward. Swabs were cultured on phenolphthalein phosphate serum agar plates which were incubated in air at $37^{\circ} \mathrm{C}$. Coagulase-positive staphylococci were phage-typed and tested for resistance to penicillin and tetracycline. Air-sampling was carried out weekly by exposing $13.5 \mathrm{~cm}$. diameter phenolphthalein phosphate serum agar plates for $8 \mathrm{hr}$. in each room. Up to ten coagulase-positive cultures from each plate 
were phage-typed and tested for resistance to penicillin and tetracycline. When more than ten colonies of Staph. aureus were present on a plate, strains were assumed to be distributed in the sample in the same ratio as in the ten colonies that had been phage-typed.

\section{Method of analysis}

Acquisition of Staph. aureus was measured by recording phage-types and antibiotic resistance of strains as they appeared in successive nasal swabs from the same patient. A strain appearing which had not been found in previous swabs or which was different in resistance or phage-type from that found previously was assumed to have been 'acquired'. The conventions adopted for times of acquisition between swabbings were those of Lidwell et al. (1966). The survey took place between November 1967 and April 1969.

\section{RESULTS \\ Incidence of sepsis}

Table 1 shows the incidence of post-operative staphylococcal wound sepsis in 11 different operation groups, arranged in increasing order of sepsis rates. There was no sepsis among 24 varicose vein operations; appendicectomy and hernia

Table 1. Incidence of staphylococcal sepsis in operation wounds

\begin{tabular}{|c|c|c|c|c|c|c|c|c|}
\hline \multirow[b]{2}{*}{ Operations } & \multicolumn{2}{|c|}{ Ward A } & \multicolumn{2}{|c|}{ Ward B } & \multicolumn{2}{|c|}{ Ward C } & \multicolumn{2}{|c|}{ All wards } \\
\hline & $\begin{array}{l}\text { No. of } \\
\text { opera- } \\
\text { tions }\end{array}$ & $\begin{array}{c}\% \\
\text { septic }\end{array}$ & $\begin{array}{l}\text { No. of } \\
\text { opera- } \\
\text { tions }\end{array}$ & $\begin{array}{c}\% \\
\text { septic }\end{array}$ & $\begin{array}{l}\text { No. of } \\
\text { opera- } \\
\text { tions }\end{array}$ & $\begin{array}{c}\% \\
\text { septic }\end{array}$ & $\begin{array}{l}\text { No. of } \\
\text { opera- } \\
\text { tions }\end{array}$ & $\begin{array}{l}\% \\
\text { septic }\end{array}$ \\
\hline Varicose veins & 7 & 0 & 3 & 0 & 14 & 0 & 24 & 0 \\
\hline Appendicectomy & 96 & 0 & 134 & 1.5 & 123 & 0 & 353 & $0 \cdot 6$ \\
\hline Hernia & 24 & 0 & 81 & $1 \cdot 2$ & 52 & 0 & 157 & $0 \cdot 6$ \\
\hline Biliary tract & 56 & 0 & 43 & $2 \cdot 3$ & 30 & $3 \cdot 3$ & 129 & $1 \cdot 6$ \\
\hline Prostatectomy & 5 & 0 & 18 & $5 \cdot 6$ & 11 & 0 & 34 & $2 \cdot 9$ \\
\hline Thyroid & 14 & 0 & 15 & $6 \cdot 7$ & 4 & 0 & 33 & $3 \cdot 0$ \\
\hline $\begin{array}{l}\text { Gastro-duodeno- } \\
\text { jejunal }\end{array}$ & 87 & $2 \cdot 3$ & 65 & $6 \cdot 2$ & 80 & $1 \cdot 3$ & 232 & $3 \cdot 0$ \\
\hline Ilio-colic-rectal & 70 & $2 \cdot 9$ & 47 & $6 \cdot 4$ & 37 & 0 & 154 & $3 \cdot 3$ \\
\hline $\begin{array}{l}\text { Miscellaneous } \\
\text { clean }\end{array}$ & 90 & $3 \cdot 3$ & 92 & $6 \cdot 5$ & 84 & 0 & 266 & $3 \cdot 4$ \\
\hline Breast & 45 & $2 \cdot 2$ & 31 & $9 \cdot 7$ & 39 & 0 & 115 & $3 \cdot 5$ \\
\hline Urological & 17 & $11 \cdot 8$ & $\mathbf{3}$ & 0 & 5 & 0 & 25 & $8 \cdot 0$ \\
\hline Total operations & 511 & $2 \cdot 0$ & 532 & $4 \cdot 1$ & 479 & 0.4 & 1522 & $2 \cdot 2$ \\
\hline
\end{tabular}

operations each gave $0 \cdot 6 \%$ staphylococcal infections and the remaining groups gave rates increasing from $1.6 \%$ for biliary to $8.0 \%$ for urological operations. The rate for all operations was $2 \cdot 2 \%$. Ward $\mathrm{C}$ had a markedly lower wound sepsis rate than wards A and B (0.4\% as against $2 \cdot 0$ and $4 \cdot 1 \%$ respectively). This could not be ascribed to the difference in numbers of the various operations performed on patients in the different wards.

Table 2 shows rates of wound and other staphylococcal infections per 100 
admissions in the three wards. The greatest number of admissions was in ward $\mathrm{A}$ (1064) and the least in ward C (841). The incidence of post-operative staphyloccocal wound sepsis was $0.9 \%$ in ward A, $2.3 \%$ in ward B and $0.2 \%$ in ward $\mathrm{C}$. The corresponding percentages for other staphylococcal sepsis were $1 \cdot 6,1 \cdot 7$ and 2.7 and for wound and/or other staphylococcal sepsis $2 \cdot 4,3 \cdot 9$, and $2 \cdot 7$. Three per cent of patients in all three wards developed staphylococcal sepsis, $1 \cdot 2 \%$ having wound sepsis and $2 \cdot 0 \%$ other sepsis. Males and females were about equally represented in each of these sepsis classes (this is not shown in the table).

The incidence of staphylococcal other sepsis in patients who had been previously admitted within 6 months was $4.1 \%$ while in those without previous admission it was only $1.7 \%$. This disproportion was most marked in the case of sepsis due to tetracycline-resistant (T) strains, the incidence being $2.8 \%$ in patients with previous admission and $0.8 \%$ in those without.

Table 2. Staphylococcal infections arising in hospital

$\begin{array}{ccccc}\text { Ward } & \text { Admissions } & \begin{array}{c}\text { Wound } \\ \text { sepsis }\end{array} & \begin{array}{c}\text { Other } \\ \text { sepsis }\end{array} & \begin{array}{c}\text { Wound or } \\ \text { other sepsis } \\ \text { staphylocots both }\end{array} \\ \text { A } & 1064 & 0 \cdot 9 & 1 \cdot 6 & 2 \cdot 4 \\ \text { B } & 958 & 2 \cdot 3 & 1 \cdot 7 & 3 \cdot 9 \\ \text { C } & 841 & 0.2 & 2 \cdot 7 & 2 \cdot 7 \\ \text { All wards } & 2863 & 1 \cdot 2 & 2 \cdot 0 & 3 \cdot 0\end{array}$

Nasal carriage of Staphylococcus aureus

The pattern of nasal carriage of Staph. aureus by patients in successive weeks of stay was somewhat different from that found by Lidwell et al. (1966) in a thoracic ward at St Bartholomew's Hospital of similar lay-out, or by Parker, John, Emond \& Machacek (1965) in patients in 1- and 2-bed cubicles at Coppett's Wood Hospital. Figs. 2 and 3 show carriage rates which were considerably lower in patients on admission and in staff (both were 18.3\%) than in the other surveys. Thus, Lidwell et al. (1966) reported $38 \%$ for patients and $39 \%$ for staff; and Parker et al. (1965), $37 \%$ for patients. In addition, the total carriage rate did not fall on successive weeks of stay as in those two surveys, but rose to a peak of $28 \%$ in week 6, a level which was however lower than the 6-week minimum of Parker et al. and only a little higher than the minimum of about $25 \%$ of Lidwell $\mathrm{et} \mathrm{al}$.

This difference lay chiefly in the very low incidence of penicillin-sensitive (S) strains on admission compared with that reported by the other workers. This fell still further during the patients' stay from $8.0 \%$ on admission to $1.5 \%$ in week 7 . The incidence of tetracycline-resistant (T) strains was $1.7 \%$ on admission, a somewhat lower level than in the other surveys, but rose steadily to $10.8 \%$ at week 6 and a peak of $17.6 \%$ at week 9 . These rates were similar to the other surveys shown in Fig. 3 for wards divided into small rooms or cubicles (A-D) but were much lower than in the unmodified open wards shown in $\mathrm{E}-\mathrm{G}$. 
The"incidence of penicillin-resistant $(\mathrm{P})$ strains rose pari passu with that for $\mathrm{T}$ strains during the first 6 weeks of stay. The rising graph of total carriage rates was therefore determined by a normally rising $\mathbf{P}$ and $\mathbf{T}$ strain graph modified by an exceptionally low $S$ strain incidence throughout the patients' stay.

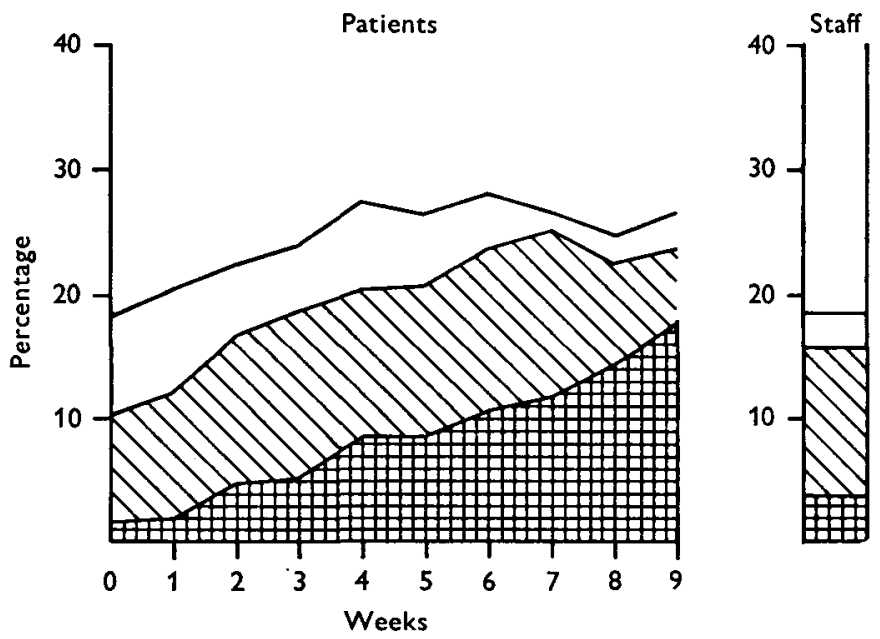

Fig. 2. Nasal carriage of Staph. aureus by patients during each week of stay in the three surgical wards. Average rate of nasal carriage by members of the staff. $\square$, Sensitive to penicillin and tetracycline; $\mathbb{N}$, resistant to penicillin only; resistant to tetracycline.

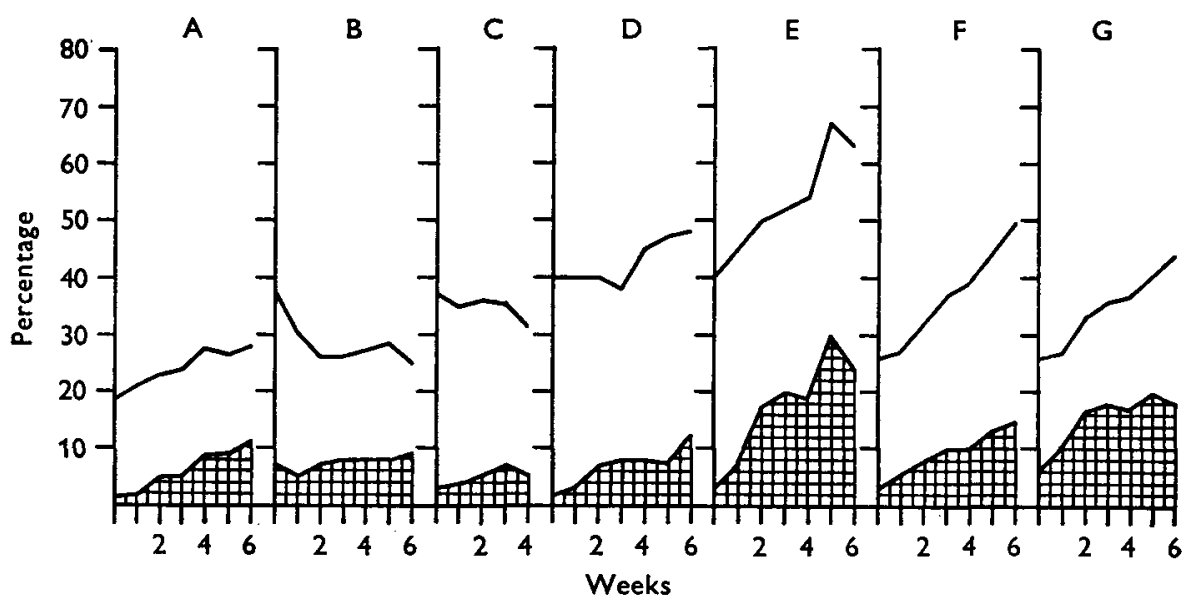

Fig. 3. Nasal carriage of Staph. aureus by patients in various hospital wards. Percentage positive in each week of stay in ward. Upper line: all strains of Staph. aureus. Lower line: tetracycline-resistant Staph. aureus [A, B, C, F and G: all tetracycline-resistant strains; $D$ and $\mathbf{E}$ : all strains resistant to penicillin and tetracycline]. A, this investigation in all three wards; $\mathbf{B}$, patients in similar lay-out, 1-bed, 4-bed and 10-bed rooms (Lidwell et al. 1966); C, patients in cubicles (Parker et al. 1965); D, E, two of three open surgical wards, D with four cubicles, E without (Williams et ai. 1962). F, medical wards; patients not receiving antibiotics; G, medical wards; patients receiving antibioties. (F, G, P.H.L.S. Cross-Infection Committee, results as given in Lidwell et al. 1966). Histograms B to $\mathrm{G}$ reproduced from Lidwell et al. (1966) by permission of Dr Lidwell. 
The influence of previous admission to hospital on carriage rate was investigated in 440 patients. The incidence of $\mathrm{S}$ strains in these patients was $6.6 \%$ and in patients not previously admitted, $8.4 \%$; that of $P$ strains was $8.6 \%$ in each group but there was a considerably greater incidence of $T$ strains in previously admitted patients $(3.4 \%)$ than in those not previously admitted $(1 \cdot 3 \%)$. This difference persisted for 2 weeks and then disappeared.

Weekly rates of carriage were calculated for the three wards A, B and C separately. Peaks occurred at different weeks in the various wards but the overall trend over 6 weeks was similar and average carriage rates were almost the same for all strains and for $\mathrm{S}$ and $\mathrm{P}$ strains. There was a somewhat higher average rate of T strains in ward A $(5.0 \%)$ than in ward $\mathrm{B}(3.4 \%)$ or ward $\mathrm{C}(3.3 \%)$ the excess occurring only in the first 3 weeks. For reasons of space the detailed figures for individual wards are not given here.

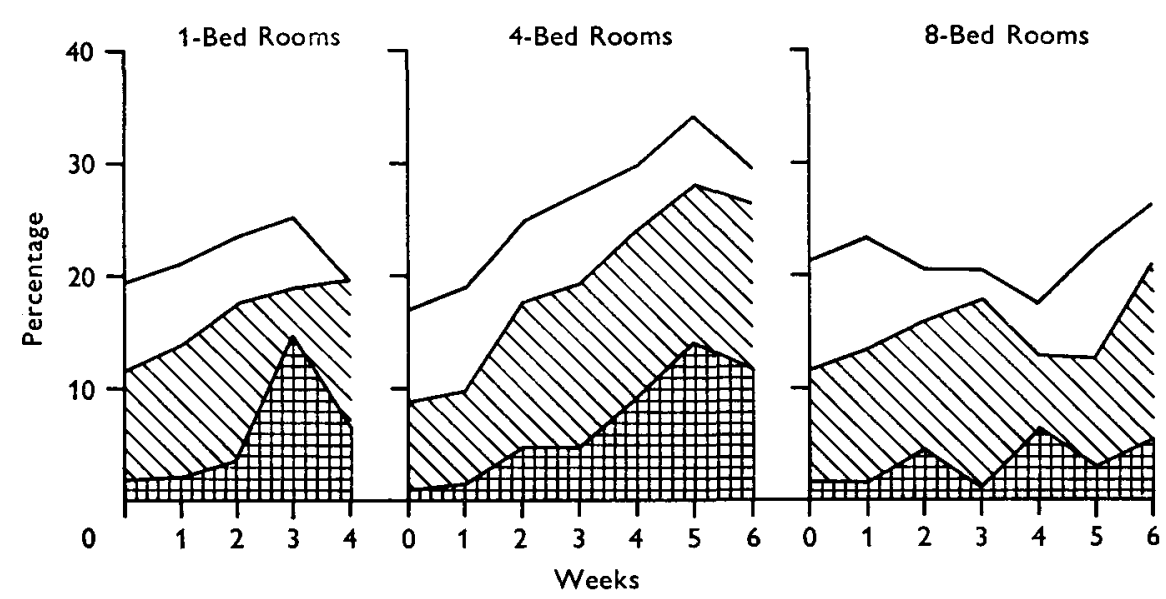

Fig. 4. Nasal carriage of Staph. aureus by patients in rooms with one bed, four beds

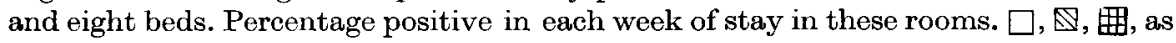
in Fig. 2.

Fig. 4 shows corresponding rates in relation to the type of room occupied by the patient throughout his or her stay. It includes only patients who had not been previously admitted to hospital within 6 months. The number of patients in 1-bed rooms became too small after 4 weeks to yield significant results but it is clear that a higher total carriage rate developed in 4-bed rooms than in either 1-bed or 8-bed rooms over the 4-6 weeks after admission. This was mainly due to a sharper rise in $\mathrm{P}+\mathrm{T}$ strains in the 4-bed rooms than in the others. There was a higher average carriage rate of $T$ strains in the 1-bed than in either 4- or 8-bed rooms during the first 4 weeks of stay, the figures for the three room types being $4 \cdot 3,3 \cdot 0$ and $2 \cdot 7 \%$ respectively.

\section{Apparent acquisition of Staphylococcus aureus}

Three hundred and seventy-one strains of Staph. aureus not found on admission were later isolated from nose swabs of patients. In 4574 patient-weeks exposure (see Table 3 ) the rate of acquisition was $8 \cdot 6$ per 100 patient-weeks, a figure rather 
higher than the $6 \cdot 4$ found in patients in small cubicles by Parker et al. (1965), and more than double the figure of $\mathbf{3 . 4}$ found in patients in the subdivided thoracic ward of Lidwell et al. (1966). However, spurious acquisition of $\mathrm{S}$ and $\mathrm{P}$ strains due to failure to isolate an organism present on admission must be taken into account. Apparent acquisition of $T$ strains is thought to be more significant than that of $P$ and $S$ strains and the present rate for $T$ strains was $2 \cdot 1$ per 100 patient-weeks as against 1.4 for the cubicle patients and $\mathbf{1 . 3}$ for the thoracic subdivided ward patients. According to Parker et al. (1965) comparable figures for multiple-resistant organisms in large open wards range from 3.7 to 12 per 100 patient-weeks. Recently, however, the unusually low figure of $3 \cdot 2$ per 100 patient-weeks has been reported by Whyte, Howie \& Eakin (1969) for T strains in open general surgical wards.

The effect of antibiotic treatment on acquisition rates is also seen in Table 3 . The rate for all strains was highest (11.3 per 100 patient-weeks) in the patients receiving tetracycline only and the rate for $\mathrm{T}$ strains was also highest in this group at 4.0 per 100 patient-weeks. Rates for all strains were not much affected by other antibiotics, but $T$ strain rates per 100 patient-weeks were 3.4 for those receiving antibiotics other than penicillin and tetracycline, $3 \cdot 1$ for patients receiving systemic antibiotics of all kinds, $2 \cdot 7$ for those having penicillin and 'other' antibiotics (i.e. not penicillin or tetracycline) $1 \cdot 3$ for penicillin only and $1 \cdot 1$ for those not receiving any antibiotics. Acquisition of $\mathrm{S}$ strains naturally tended to be less when antibiotics were given $(1 \cdot 3-2 \cdot 9)$ than when no antibiotics were given $(3 \cdot 1)$. An exception was in the tetracycline only group when a rate of 4.0 per 100 patientweeks was recorded.

Apparent acquisitions of Staph, aureus in relation to presumed sources are given in Table 4. In 233 strains no source was found within 10 days before the acquisition, and 42 were non-typable. Of the remainder, 72 strains were from known singlepatient sources, of which 27 were $T$ strains; 20 strains (including $6 \mathrm{~T}$ strains) came from a patient or patients in the same room as the recipient, 42 (15 T strains) from patients in other rooms, 27 (12 $\mathrm{T}$ strains) from staff and 14 (7 $\mathrm{T}$ strains) from patients in other wards.

In comparing rates of acquisition in relation to source with those reported by Lidwell et al. (1966), it seems best to pay attention mainly to rates for $T$ strains (Table 4) as these are less likely to be spurious than those of $\mathrm{P}$ and $\mathrm{S}$ strains. The rates per 100 patient-weeks for patient-sources in the same room as the recipient $(0 \cdot 13)$, in other rooms $(0 \cdot 33)$, and from staff $(0 \cdot 26)$, compared with the corresponding figures derived from the above publication of $0 \cdot 11,0 \cdot 29$ and $0 \cdot 14$ respectively. The first two figures were similar in the two surveys, but the third figure, for staff sources, was larger in the present series than in the other.

Nasal acquisition of Staph. aureus from the 72 single-patient sources was further analysed according to the mobility and site of the source-patient and the roomtype of the recipient in the week before the acquisition. Relatively few acquisitions (4) occurred from ambulant patient sources. The great majority were from patients who were up occasionally (35 total, $12 \mathrm{~T}$ strains) and from bed-fast patients (33 total, $13 \mathrm{~T}$ strains). On the other hand, 8 out or 12 source-patients who were in. 
Table 3. Apparent acquisition of nasal Staphylococcus aureus by patients in relation to antibiotic treatment

(Rate per 100 patient-weeks exposure. $S=$ sensitive to penicillin and tetracycline, $\mathrm{P}=$ resistant only to penicillin. $\mathbf{T}=$ resistant to tetracycline.)

Antibiotic
treatment
and strains

and strains

All patients

All strains

$\mathrm{S}$

$\mathbf{P}$

$\mathrm{T}$

No antibiotic

All strains

S

$\mathbf{P}$

$\mathrm{T}$

Systemic antibiotic

All strains

$\mathrm{S}$

$\mathrm{P}$

$\mathrm{T}$

Penicillin only

All strains

$\mathrm{S}$

$\mathbf{P}$

$\mathrm{T}$

Tetracycline only

All strains

$\mathrm{S}$

$\mathrm{P}$

$\mathrm{T}$

Other only*

All strains

$\mathrm{S}$

$\mathrm{T}$

Penicillin and other*

All strains

$\mathrm{S}$

$\mathrm{P}$

$\mathbf{T}$

Tetracycline and other*

All strains

$\mathrm{S}$

$\mathrm{P}$

$\mathrm{T}$
No. of

patient-weeks exposure

4574
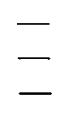

2156
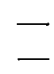

-

$-$

2393
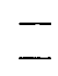

$-$

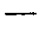

77

- 6.5

$-$

$\overline{-}$

150

-

二

二

$$
\begin{gathered}
\text { Rate of } \\
\text { acquisition } \\
\text { of strains }
\end{gathered}
$$

1365

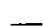

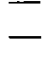

$-$

$-$

743

$\begin{array}{ll}- & 9 \cdot 0 \\ - & 1.9 \\ - & \mathbf{4 . 4} \\ - & 2.7\end{array}$

34

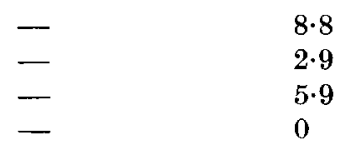

* Antibiotics other than penicillin or tetracycline. 
other wards were either ambulant or up occasionally. Table 5 subdivides these figures. There was a predominance of $T$ strain acquisitions in 1-bed rooms (6 among a total of 12 beds), as compared with 4-bed rooms (13 among 48 beds) or 8-bed rooms (8 among 24 beds). In both 4 - and 8-bed rooms, the proportion of acquisitions of all strains from sources in other rooms to those in the same room was about $2: 1$; the corresponding ratios for $T$ strains were $1 \cdot 6: 1$ in 4 -bed and $3: 1$ in 8 -bed rooms. There was no greater tendency for patients who were up occasionally to act as other-room sources than patients who were bed-fast.

Table 4. Apparent acquisition of Staphylococcus ureus in relation to a presumed source

(Patient-weeks of exposure 4574.)

\begin{tabular}{|c|c|c|c|c|c|c|c|c|}
\hline \multirow[b]{3}{*}{ Source } & \multicolumn{4}{|c|}{ No. of 'acquired' strains } & \multicolumn{4}{|c|}{$\begin{array}{l}\text { Rate of acquisition } \\
\text { per } 100 \text { patient-weeks }\end{array}$} \\
\hline & \multicolumn{4}{|c|}{$\begin{array}{c}\text { Antibiotic resistance } \\
\text { of strains }\end{array}$} & \multicolumn{3}{|c|}{$\begin{array}{c}\text { Antibiotic resistance } \\
\text { of strains }\end{array}$} & \multirow{2}{*}{$\begin{array}{l}\text { All } \\
\text { strains }\end{array}$} \\
\hline & $\mathbf{S}$ & $\mathrm{P}$ & $\mathbf{T}$ & strains & $\mathbf{S}$ & $\mathbf{P}$ & $\mathbf{T}$ & \\
\hline Known single patient & 15 & 30 & 27 & 72 & $0 \cdot 33$ & $0 \cdot 66$ & 0.59 & $1 \cdot 57$ \\
\hline Patient(s) in same room & 10 & 4 & 6 & 20 & $0 \cdot 22$ & 0.09 & $0 \cdot 13$ & $0 \cdot 44$ \\
\hline $\begin{array}{l}\text { Patient(s) in other } \\
\text { room }\end{array}$ & 7 & 20 & 15 & 42 & $0 \cdot 15$ & $0 \cdot 44$ & $0 \cdot 33$ & 0.92 \\
\hline $\begin{array}{l}\text { Patient(s) in same/ } \\
\text { other room }\end{array}$ & 0 & $\mathbf{I}$ & 3 & 4 & 0 & $0 \cdot 02$ & $0 \cdot 07$ & 0.09 \\
\hline Patients or staff & 1 & $\mathbf{3}$ & 1 & 5 & $0 \cdot 02$ & $0 \cdot 07$ & $0 \cdot 02$ & $0 \cdot 11$ \\
\hline Staff & 4 & 11 & 12 & 27 & 0.09 & $0 \cdot 24$ & $0 \cdot 26$ & 0.59 \\
\hline $\begin{array}{l}\text { No source within } \\
\text { ten days }\end{array}$ & 83 & 110 & 40 & 233 & $1 \cdot 82$ & $2 \cdot 40$ & $0 \cdot 87$ & $5 \cdot 09$ \\
\hline Non-typable & 8 & 22 & 12 & 42 & $0 \cdot 18$ & $0 \cdot 48$ & $0 \cdot 26$ & 0.92 \\
\hline Patient(s) in other ward & 1 & 6 & 7 & 14 & 0.02 & $0 \cdot 13$ & $0 \cdot 15$ & $0 \cdot 31$ \\
\hline
\end{tabular}

Sources of staphyloccocal sepsis

Presumed sources of staphylococcal wound and other sepsis are shown in Table 6. In wound sepsis, the source was unknown in 13 out of 34 strains; of the remainder, the majority could be traced to other patients or staff (12), the rest coming from the patient himself (9). In other staphylococcal sepsis the majority of known-source strains came from the nose of the patient himself (16 out of 29). Eight strains originated from other patients, four from staff and one from patients or staff. About half of all 'other sepsis' strains had no known source ( 30 out of 59). There was a predominance of $T$ strains in both types of sepsis.

\section{Staphylococcus aureus in the air}

Two thousand and thirty-one culture plates were exposed for $8 \mathrm{hr}$. each in the 27 rooms of the three wards. Two thousand and fifty colonies of Staph.aureus grew on these plates. Assuming that the number of bacteria-carrying particles settling on $1 \mathrm{ft} .^{2}$ of culture medium per minute is approximately equal to the number per $\mathrm{ft}^{3}$ of air (Williams, Blowers, Garrod \& Shooter, 1966), this gives an approximate 
Infection in subdivided wards

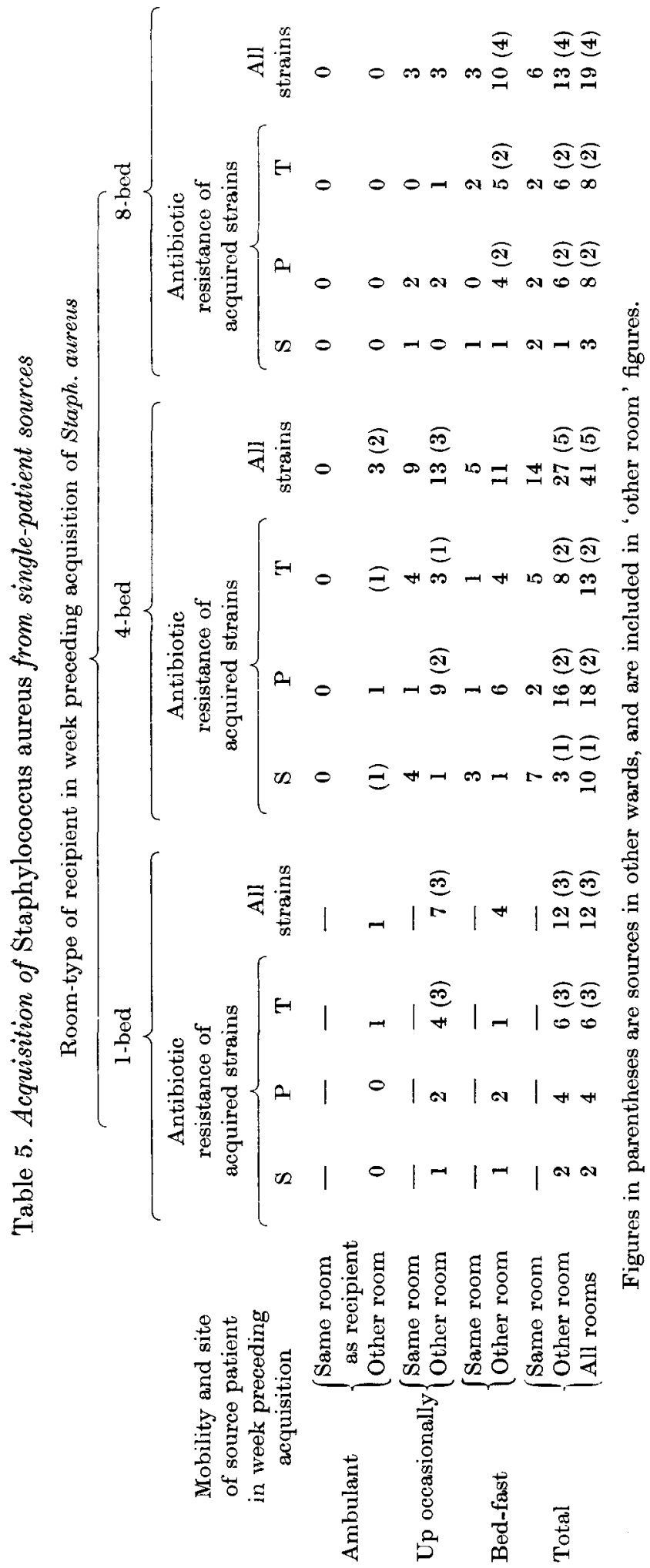


average air content of $49 \cdot 5 \mathrm{Staph}$. aureus-carrying particles per $100 \mathrm{~m} .^{3}(14 \cdot 0$ per $1000 \mathrm{ft}^{3}{ }^{3}$. This is less than half the average figure reported by Lidwell et al. (1966) of 124 per $100 \mathrm{~m}^{3}$ ( 35 per $1000 \mathrm{ft}^{3}$ ), which was in turn much lower than the values observed earlier in open surgical wards at St Bartholomew's Hospital. Average counts were then between 635 and 776 per $100 \mathrm{~m}^{3}$ air (180 and 220 per $1000 \mathrm{ft}^{3}$ (Noble, 1962).

Table 7 shows the average estimated air contents in the various wards and room types. Wards A and B were roughly equal (62.3 and $60 \cdot 4$ per $100 \mathrm{~m} .^{3}$ respectively), but ward $\mathrm{C}$ gave less than half of these $\left(24 \cdot 1\right.$ per $\left.100 \mathrm{~m} .^{3}\right)$. There were fewer Staph. aureus particles in the air of the 1-bed rooms than in 4- or 8-bed rooms. Total strains are given in Table 8 for each room type, the average numbers per $100 \mathrm{~m} .^{3}$ air for 1-, 4- and 8-bed rooms being $36 \cdot 8,60 \cdot 2$ and $53 \cdot 8$ respectively. Note the

\section{Table 6. Presumed sources of staphylococcal sepsis}

\begin{tabular}{|c|c|c|c|c|c|c|c|}
\hline & & & Presu & med s & ource & & \\
\hline $\begin{array}{l}\text { Type of } \\
\text { infection }\end{array}$ & & Self & $\begin{array}{l}\text { Another } \\
\text { patient } \\
\text { or } \\
\text { patients }\end{array}$ & Staff & $\begin{array}{c}\text { Staff } \\
\text { or } \\
\text { patients }\end{array}$ & $\begin{array}{c}\text { Not } \\
\text { known }\end{array}$ & $\begin{array}{l}\text { Total } \\
\text { sepsis } \\
\text { strains }\end{array}$ \\
\hline & is & 0 & 0 & 1 & 2 & 4 & 7 \\
\hline Staphylococcal & $\mathbf{P}$ & 5 & 2 & 0 & 0 & 4 & 11 \\
\hline wound sepsis & $\mathrm{T}$ & 4 & 6 & 1 & 0 & 5 & 16 \\
\hline & All strains & 9 & 8 & 2 & 2 & 13 & 34 \\
\hline & $(\mathrm{S}$ & 1 & 1 & 0 & 0 & 3 & 5 \\
\hline Staphylococcal & $\mathbf{P}$ & 6 & 0 & 2 & 1 & 15 & 24 \\
\hline other sepsis & $T$ & 9 & 7 & 2 & 0 & 12 & 30 \\
\hline & All strains & 16 & 8 & 4 & 1 & 30 & 59 \\
\hline
\end{tabular}

unexpected finding of the slightly greater number in 4-bed than in 8-bed rooms. There was a lower proportion of $T$ strains to all strains in ward $C$ than in wards $A$ and $B$ (Table 7) and this was true in each of the three room types.

The tendency of 1-bed rooms to yield fewer staphylococci than 4- or 8-bed rooms was reversed for $T$ strains in ward $B$, there being $28 \cdot 2,19 \cdot 9$ and $12 \cdot 2$ colonies per $100 \mathrm{~m}^{3}$ air in the three respective types of room. This was due to the exceptionally potent source-patient described below, whose room air yielded more than half the total $\mathrm{T}$ strains from 1-bed rooms in this ward.

Table 8 shows the distribution of sources of aerial strains. In each room-type the proportion of strains originating from single-patient sources in other rooms to those from the same room was about $1: 2$. This was the same for all rooms in ward $A$ and $B$, but in ward $C$ the ratio was $1: 3$. Other-room sources in this ward were therefore less important in aerial spread than in wards $A$ and $B$.

The number of strains traced to single members of staff were between $2 \cdot 7$ and 3.8 per $100 \mathrm{~m} .{ }^{3}$ air for the three types of room. The corresponding figures for wards $\mathrm{A}, \mathrm{B}$ and $\mathrm{C}$ were $5 \cdot 0,4 \cdot 1$ and $0 \cdot 7$ respectively, the last figure being a particularly low one not only in relation to other wards, but also in relation to patient-sources in the same ward. 


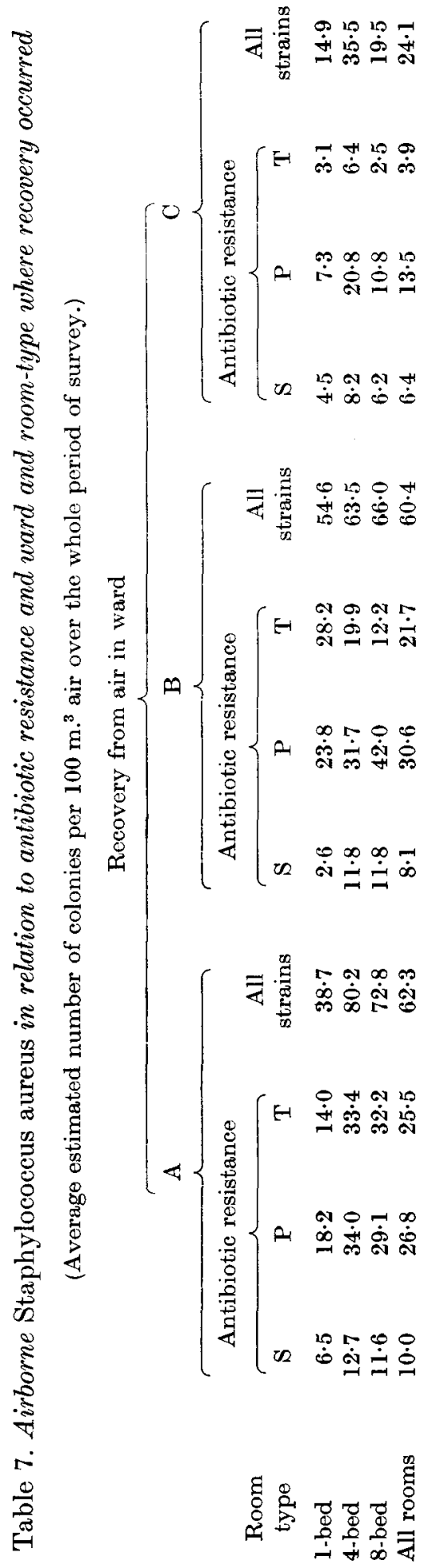


Table 8. Airborne Staphylococcus aureus in relation to sources

(Estimated colonies per $100 \mathrm{~m}^{3}$ air. 1-b, 4-b, 8-b = 1-, 4-, 8-bed rooms.)

Location of source carriers.

\begin{tabular}{|c|c|c|c|c|c|c|c|}
\hline \multirow{2}{*}{$\begin{array}{l}\text { Recovery } \\
\text { from air } \\
\text { Rooms }\end{array}$} & \multicolumn{2}{|c|}{$\begin{array}{l}\text { Single-patient } \\
\text { sources }\end{array}$} & \multirow[b]{2}{*}{$\begin{array}{l}\text { Other } \\
\text { ward }\end{array}$} & \multirow[b]{2}{*}{$\begin{array}{l}\text { Single } \\
\text { staff } \\
\text { sources }\end{array}$} & \multirow[b]{2}{*}{$\begin{array}{c}>1 \\
\text { source }\end{array}$} & \multirow[b]{2}{*}{$\begin{array}{l}\text { No } \\
\text { known } \\
\text { source }\end{array}$} & \multirow[b]{2}{*}{ Total } \\
\hline & $\begin{array}{l}\text { Same } \\
\text { room }\end{array}$ & $\begin{array}{l}\text { Other } \\
\text { room }\end{array}$ & & & & & \\
\hline $1-b$ & $11 \cdot 5$ & $5 \cdot 4$ & 0.8 & $3 \cdot 7$ & $4 \cdot 2$ & $11 \cdot 1$ & $36 \cdot 8$ \\
\hline 4-b & $15 \cdot 0$ & $6 \cdot 3$ & $1 \cdot 4$ & $2 \cdot 7$ & $3 \cdot 4$ & $31 \cdot 4$ & $60 \cdot 2$ \\
\hline $\begin{array}{l}\text { 8-b } \\
\text { Wards }\end{array}$ & $12 \cdot 6$ & $7 \cdot 2$ & 0.5 & $3 \cdot 8$ & $2 \cdot 2$ & $27 \cdot 6$ & $53 \cdot 8$ \\
\hline A & $10 \cdot 0$ & $5 \cdot 0$ & $2 \cdot 4$ & $5 \cdot 0$ & $2 \cdot 3$ & $37 \cdot 8$ & $62 \cdot 3$ \\
\hline B & $19 \cdot 7$ & $10 \cdot 1$ & 0.3 & $4 \cdot 1$ & $6 \cdot 3$ & $20 \cdot 0$ & $60 \cdot 4$ \\
\hline $\mathrm{C}$ & $9 \cdot 2$ & $\mathbf{3} \cdot 0$ & $0 \cdot 3$ & 0.7 & $1 \cdot 8$ & $9 \cdot 2$ & $24 \cdot 1$ \\
\hline $\begin{array}{l}\text { All rooms } \\
\text { All wards }\end{array}$ & $13 \cdot 1$ & $6 \cdot 1$ & $1 \cdot 0$ & $\mathbf{3} \cdot \mathbf{3}$ & $3 \cdot 5$ & $22 \cdot 6$ & $49 \cdot 5$ \\
\hline
\end{tabular}

\section{Broadcasts of Staphylococcus aureus}

The term 'broadcast' here means the isolation of ten or more colonies of Staph. aureus of a particular phage type and antibiotic resistance on any one weekly sampling day or 15 or more colonies on two successive sampling days. In ward A there were eight such broadcasts during the survey, yielding 152 colonies; in ward B there were twelve, yielding 454 colonies; and in ward C, four, yielding 80 colonies. Broadcasts were therefore largest and most frequent in ward B and smallest and least frequent in ward $\mathrm{C}$. One of them came from an unusually potent source of staphylococci-a patient in a 1-bed room with tumour obstruction of the larynx and a tracheostomy wound infected with Staph. aureus. Over a period of 8 weeks no fewer than 146 colonies from this source were isolated from the routine weekly plates in ward B. There were two phage types involved, the first being a $\mathrm{P}$ strain, yielding 20 colonies, the second, a $\mathrm{T}$ strain, yielding 126 colonies. The latter strain was found in every room in the ward on one or more occasions and also in three rooms in ward A. Its highest concentration was in the patient's room, when on one occasion 70 colonies were estimated to be present on one 8-hr plate, corresponding to about 3300 staphylococcal particles per $100 \mathrm{~m} .^{3}$ air $(970$ per $1000 \mathrm{ft}^{3}{ }^{3}$ ). During the broadcast, the patient was either bed-fast or up occasionally.

Six of the broadcasts were of $\mathrm{T}$ strains, 14 of $\mathrm{P}$ strains and four of $\mathrm{S}$ strains. Apart from the patient described above, there was no obvious tendency for $T$ strain broadcasts to be larger than those of $P$ strains, but those of $S$ strains were much smaller.

Two broadcasts of $\mathrm{P}$ strains were traced to staff, both nurses. One further broadcast came from either a patient or a nurse or both. 


\section{Spread of staphylococci between wards}

One case of wound sepsis in ward B yielded a staphylococcus indistinguishable from a strain carried by a patient in ward A and by another in ward C, either of whom could have been the source. Nasal acquisitions from single-patient sources in other wards appeared to originate in ward A on two occasions, ward B on six occasions and ward $C$ on four occasions. The direction of spread was from ward $\mathrm{A}$ to $\mathrm{B}$ once, $\mathrm{A}$ to $\mathrm{C}$ once, $\mathrm{B}$ to $\mathrm{A}$ twice, $\mathrm{B}$ to $\mathrm{C}$ four times and $\mathrm{C}$ to $\mathrm{A}$ three times.

Staph. aureus from sources in other wards was recovered from the air of bedrooms on a total of seventeen occasions, nine in ward A, four in ward B and four in ward C. Ward B was the source on seven occasions, spread occurring to ward A on six occasions and to ward $\mathrm{C}$ on one of these occasions. Ward $\mathrm{C}$ was the source on six occasions, spreading on three occasions each to wards A and B. Ward A was only once definitely shown to be a source, spread occurring to ward B.

\section{DISCUSSION}

The incidence of post-operative wound sepsis was lower than that found in the same unit in 1962 , when $5 \cdot 6 \%$ of clean and potentially infected operation wounds and $8.3 \%$ of all admissions to the general surgical wards developed staphylococcal sepsis (figures for unit (A) male and female wards, in Edmunds et al. 1965). This was a degree of sepsis commonly found in open wards, e.g. $5 \cdot 2 \%$ of operation wounds derived from the Report (1960) and $5 \cdot 6 \%$ of admissions from Williams et al. (1959). The present figures were $2 \cdot 2 \%$ for wounds and $3.0 \%$ for admissions, clearly a considerable reduction, which can be attributed to the opening of an extension to the hospital shortly before the start of the survey; this enabled general surgical patients to be accommodated in three wards (A, B and C) with both sexes represented in each ward, instead of the two allocated to the speciality before (A, male, B, female). This prevented the overcrowding which was common before, and was associated with a nearly equal division of sepsis between the sexes, in place of the previous much higher incidence among the males.

The very low rate of staphylococcal wound sepsis in ward $\mathrm{C}(0 \cdot 4 \%)$ could have been related to the lower turnover of patients and greater stairwell ventilation by fresh air than in the other wards. However, the rate of staphylococcal other sepsis was higher than in other wards and nasal carriage rates were similar, so that one's attention was directed to possible differences in regimen affecting only those patients who had operations. The most likely seemed to be the routine administration of penicillin and streptomycin at and after operation in ward C. If this was a major cause for the low wound sepsis rate it would bear out the experience of Lidwell et al. (1966) that extensive use of antibiotics can under certain circumstances be a factor in reducing wound sepsis. The synergistic action of penicillin and streptomycin might well be effective even against penicillinaseproducing staphylococci, but many people would not accept the risk of ototoxicity involved in the prophylactic use of streptomycin.

In common with other recent reports on subdivided wards, carriage rates were 
considerably lower than those reported from large open wards. The influence of previous admission to hospital was not significant for $S$ and $P$ strains, but the carriage rate of $\mathrm{T}$ strains was 2.5 times higher in previously admitted patients than in the others; and this was associated with a higher staphylococcal sepsis rate, particularly due to $\mathrm{T}$ strains, in the former group.

An unexpected finding was that carriage rates of $\mathrm{P}$ and $\mathrm{T}$ strains rose more sharply in patients in 4-bed rooms than in 8-bed rooms. There was also a slightly higher average staphylococcal content of the air in the smaller rooms than in the larger. These facts may be related to the more severe illnesses and more intensive treatment of patients in the smaller rooms, and the exclusive occupancy of 8-bed rooms by females, who are less prolific sources of staphylococci than males (Blowers \& McCluskey, 1965). In addition the air space per bed was greater than in other room types. These factors probably also explain the higher acquisition and average carriage rates of $T$ strains in 1-bed rooms than in other rooms.

Nasal acquisition rates, both of antibiotic-sensitive and resistant strains were lower than in open wards, though not so low as those reported by Lidwell $e t$ al. (1966) in a similar architectural layout. The latter difference may be related to the smaller proportion of patients receiving antibiotics in this unit (37\%) as compared with the other $(71 \%)$.

Lidwell et al. (1966) found that there was more acquisition of staphylococci from patient-carriers in other rooms than from those in the same room as the recipient. This was confirmed in this investigation, the proportion of other-room to sameroom sources of $\mathrm{T}$ strains being the same (about 2.5 to 1 ); however, nearly twice as many such acquisitions occurred from staff in this series as in the other.

It seems unlikely that the degree of ambulation of potential source carriers was of much importance in the spread of infection, as fully ambulant single-patient sources were in a very small minority, the great majority being up occasionally (i.e. for $2 \mathrm{hr}$. or less per day) or bed-fast. This leaves out of account the majority of acquisitions where patient sources were less well defined and it was therefore not possible to assess their degree of mobility. Nevertheless the ability of bed-fast patients to act as sources of staphylococcal acquisitions was noteworthy.

The low air counts of Staph. aureus particles may be explained in part by the long period over which the survey extended. The great majority of colonies were isolated on very few occasions while many weeks exposure yielded no colonies at all. Thus sampling limited to a shorter period might have yielded higher or lower average counts than that reported here, depending on whether or not broadcasts were included. In spite of this, however, the amount of aerial spread of Staph. aureus was clearly of a lower order than in open wards.

Ward $\mathrm{C}$, in addition to a lower wound sepsis rate than wards $\mathrm{A}$ and $\mathrm{B}$, had a lower average air count of staphylococci and was the site of fewer broadcasts. This was probably due to factors already suggested including a different antibiotic regimen, lower patient turnover and different ventilation, none of which was related to the architecture or design of the ward units themselves. On the other hand, average staphylococcal carriage rates were not significantly different in the three wards, and sepsis other than wound sepsis was more frequent in ward $\mathrm{C}$ than 
in the other wards. In view of these facts it would seem desirable to study several identical units simultaneously if a proper assessment is to be made of the role of architecture in the spread of infection.

I am grateful to Mr J.W. M. Sutherland, Mr W. Drummond and Mr B. C. Abernethy for permission to study their patients, to the matron, sisters and nursing staff of the wards for their co-operation, to the Scottish Home and Health Department for financial support and to the data processing unit of the South Eastern Regional Hospital Board (Scotland) for help in analysis. I wish also to thank Professor R. E. O. Williams, Professor R. A. Shooter and Dr O. M. Lidwell for their advice and help, Dr J. D. Barrie for carrying on the project during my illness and Mr A. C. Heddle and Mrs M. Bailey for technical assistance.

\section{REFERENCES}

Blowers, R. \& MCCluskey, M. (1965). Design of operating room dress for surgeons. Lancet ii, 681.

Edmunds, P. N., Drummond, W., Chalmers, T. S., Gillie, T. A., Whitelaw, R. G., Train, T. S. R., Paterson, W. I. \& Spence, A. J. (1965). Sepsis in three Scottish nonteaching hospitals. Scottish Medical Journal 10, 209.

Lidwell, O. M., Polakoff, S., Jevons, M. P., Parker, M. T., Shooter, R. A., French, V. I. \& DUNKERLEY, D. R. (1966). Staphylococcal infection in thoracic surgery: experience in a subdivided ward. Journal of Hygiene 64, 321.

Noble, W. C. (1962). The dispersal of staphylococci in hospital wards. Journal of Clinical Pathology 15, 552.

Parker, M. T., John, M., Emond, R. T. D. \& Machacek, K. A. (1965). Acquisition of Staphylococcus aureus by patients in cubicles. British Medical Journal i, 1101.

REPORT (1960). Incidence of surgical wound infection in England and Wales. Lancet ii, 659.

WhYTe, W., Howte, J. G. R. \& EAKIN, J. E. (1969). Bacteriological observations in a mechanically ventilated experimental ward and in two open-plan wards. Journal of Medical Microbiology 2, 335.

Williams, R. E. O., Blowers, R., Garrod, L. P. \& Shooter, R. A. (1966). Special technical methods. In Hospital Infection, 2nd ed. p. 362. London: Lloyd-Luke (Medical Books) Ltd.

Williams, R. E. O., Jevons, M. P., Shooter, R. A., Hunter., C. J. W., Girling, J. A., Griffites, J. D. \& TAYlor, G. W. (1959). Nasal staphylococci and sepsis in hospital patients. British Medical Journal ii, 658.

Williams, R. E. O., Noble, W. C., Jevons, M.P., Lidwele, O. M., Shooter, R. A., White, R. G., Tном, B. T. \& TAYlor, G. W. (1962). Isolation for the control of staphylococcal infection in surgical wards. British Medical Journal ii, 275. 